\title{
Bank Lending, Inflation, and China's Stock Market (2004-2010)
}

\author{
Richard C. K. Burdekin ${ }^{1,2}$ and Ran Tao ${ }^{1,2}$ \\ ${ }^{1}$ Robert Day School of Economics \& Finance, Claremont McKenna College, 500 E. Ninth Street, Claremont, CA 91711, USA \\ ${ }^{2}$ Economics Department, University of Wisconsin-Whitewater, WI 53190, USA
}

Correspondence should be addressed to Richard C. K. Burdekin, rburdekin@cmc.edu

Received 22 August 2011; Accepted 31 August 2011

Academic Editor: James R. Barth

Copyright ( 2011 R. C. K. Burdekin and R. Tao. This is an open access article distributed under the Creative Commons Attribution License, which permits unrestricted use, distribution, and reproduction in any medium, provided the original work is properly cited.

The 2009 surge in bank lending in China was accompanied by allegations of substantial funds being funneled into the nation's stock and property markets. This paper uses 2004-2010 People's Bank survey data to examine the possible linkages between banking activity and the stock market as well as the associated inflation risks. In general, stock market strength in China seems to be accompanied by rising inflationary concerns, increased bank lending activity, and reduced banker confidence that stable conditions will be maintained. This suggests that the Shanghai market could serve as a useful indicator variable for Chinese monetary policy.

\section{Introduction}

The bad loan problems of China's large state-owned commercial banks (SOCBs) have been well documented, as have the successive capital infusions and balance sheet cleanups that allowed Bank of China (BOC), Bank of Communications (BOCOM), China Construction Bank (CCB), and Industrial and Commercial Bank of China (ICBC) to go public in 2005-2006, followed by Agricultural Bank of China $(A B C)$ in 2010. Reports of rising bank profitability have been accompanied by allegations that substantial amounts of the funds lent were being used not in financing real economic activity but in speculation in the nation's stock and property markets, however. Such claims came to a head in 2009 with a surge in bank lending prompted by Chinese government efforts to support the economy during the global financial crisis. Bank loan issuance in the first half of 2009 alone totaled RMB 7.37 trillion, exceeding the full-year total from 2008. This was accompanied by a $60 \%$ rise in the Shanghai stock market over the first six months of 2009, with many observers pointing to large sums being "diverted into shares and property" [1]. Wei Jianing, Deputy Minister of State Council Research Center's macroeconomics department, estimated that about $20 \%$ of total bank credit flowed into the stock market in the early months of 2009. ${ }^{1}$ Many business owners simply transferred funds borrowed under the government's easy money policy to an account with another bank, from which they could enter the stock market away from the scrutiny of the original lender. ${ }^{2}$

Full-year lending in 2009 totaled RMB 9.6 trillion, representing nearly half of that year's GDP. Although the China Banking Regulatory Commission (CBRC) released reports from some regions that two to three percent of funds were misappropriated [2], there are, of course, no official time series documenting just how much money was actually illegally channeled into the stock market. There are, however, survey data collected by People's Bank of China that, while not allowing us to determine the exact sums involved, offer an interesting window into the possible link between bank lending and China's stock market. We also utilize People's Bank survey data on inflation expectations to consider the perceived inflation risk that might be associated with intensified banking activity and stock market gains. Our empirical work identifies causal relationships between the stock market and the survey-based banking series as well as with inflation expectations. The linkages between bank lending, the stock market and overheating concerns are in line with the inflationary risks attributed to asset price booms elsewhere in East Asia by M.S. Gochoco-Bautista [3]. Although the question of whether monetary policy should react to asset prices remains highly controversial, medium-term inflation targeting implies that the central bank should react to booms that are 
"expected to produce overheating in the near future" [4]. Such expectations certainly seem to be prevalent in the 2004-2010 Chinese experience assessed below.

\section{Banker Sentiment, Inflation Expectations, and the Shanghai Stock Market}

Beginning in the first quarter of 2004, the People's Bank of China has reported quarterly survey data based on a sample of 2900 different banking institutions (including rural cooperatives). The survey is answered by those in charge at the bank's headquarters, presidents of first and second-rank branches or vice presidents who are in charge of loans and credits. The survey results reflect quarter-to-quarter comparisons for the following two measures.

(i) The Banking Business Index (after first excluding any institutions providing a "not sure" response) calculates the proportion $\left(c_{i}\right)$ of banker responses on the level of their business within five weighted $\left(q_{i}\right)$ categories ranging from "Very Good" = 1, "Good" = 0.75, "OK" = 0.5, "Bad" = 0.25 , to "Very Bad" $=0$. The resulting formula is given by $I=\sum_{i=1}^{5} c_{i} q_{i}$. Each category must lie between $0-100 \%$, in percentage terms, and index values above 50\% suggest expansion and index values below 50\% indicate contraction.

(ii) The Index of Bankers' Confidence is the arithmetic average of the proportion of bankers who believe this quarter's economy is normal and the proportion of bankers who expect conditions to be normal going forward. ${ }^{3}$

The banking survey data offer a perspective from toplevel officials across a very wide range of China's banking institutions. The two series also have the advantage of reflecting sentiment on current conditions whereas standard bank performance measures continue to be heavily influenced by historical factors and preexisting conditions. For example, the SOCBs had longstanding bad loans to loss-making stateowned enterprises (SOEs), while successive government recapitalizations affected not only the large SOCBs but also the city commercial banks and other institutions. ${ }^{4}$ Although the sample period for the sentiment series is limited, the 2004 start date precedes the IPOs of four of the five large SOCBs in 2005-2006 and also encompasses a number of sharp swings in China's economy. Surging economic growth and growing capital inflows led to repeated concerns with the rate of credit expansion from 2003 to 2007 that spurred a series of tightening measures by the People's Bank and government pressure on commercial banks to rein in lending (see, e.g., [5, chapter 4]). This was followed by a shift toward concerns of slowdown and even deflation as the global financial crisis hit home in 2008, prompting a large government stimulus program (equivalent to \$US 600 billion or $20 \%$ of China's GDP) supported by demands for more rapid loan growth by the banking system. The pendulum swung back again as renewed concerns about overheating and excess lending reemerged by the middle of 2009, seemingly justifying the monetary tightening undertaken in response [6]. ${ }^{5}$

Stock market sensitivity to such policy swings would be in line with Sun et al. [7] finding that a significant asset price channel has operated alongside bank lending and interest rate channels in China's monetary transmission mechanism during 1996-2006, seemingly pointing to the importance of wealth effects. ${ }^{6}$ Over our 2004-2010 sample period, 2006 marks the first big rise in the Shanghai A-share index, when the market more than doubled before rising by a further 96\% in 2007. ${ }^{7}$ The Shanghai A-share index subsequently declined dramatically in 2008, more so than most other world markets. In falling below 2000 in October 2008, the market registered a more than $75 \%$ drop relative to its peak above 6000 in October 2007. The market rebounded sharply in 2009, however, as lending rates accelerated dramatically following the launch of the government's stimulus package in November 2008. In addition to the stock market boost stemming from the overall relaxation of credit constrains, the Shanghai Stock Exchange stood to especially benefit from any increase in investor demand for bank shares, given their pivotal role in the index. Indeed, over the June 1, 2006 to November 15, 2007 period, Yao et al.'s [8] causality testing supports a unidirectional causal relationship between most bank stock prices and the Shanghai Composite Indexincluding CCB and ICBC, which in 2006 became the largest two banks in the world by market capitalization. ${ }^{8}$

Our analysis examines the relationship between the two bank survey measures and the stock market during 20042010 while also incorporating People's Bank survey data on "Current Price Satisfaction" and "Future Price Expectation" to take into account inflation concerns. Both of these latter series are based on approximately 20,000 questionnaires returned from 50 large-, medium-, and small-sized cities across the country. The Current Price Satisfaction index simply reflects people's stated level of satisfaction with current prices. The higher the index, the greater the satisfactionand the less those surveyed appear to be worrying about inflation. Meanwhile, higher values of Future Price Expectation imply increasing concerns about future inflation. Thus, insofar as higher bank lending rates lead to concerns about overheating, we would expect a rising Banking Business Index to be accompanied by falling Current Price Satisfaction and rising Future Price Expectation. In the analysis below, we examine the empirical support for this proposition in addition to testing for causal relationships between the banking measures and stock market performance. We utilize the complete set of available survey data from the first quarter of 2004 though the last quarter of $2010 .^{9}$

\section{Data Analysis and Causality Testing Results}

The sharp ups and downs in the stock market over our 20042010 period, along with the accompanying movements in the Banking Business Index, can be seen in Figure 1. The stock market values reflect the end-of-quarter close of the Shanghai A-share index. ${ }^{10}$ The apparent comovement of the two series is also reflected in a high correlation coefficient of 0.724 (Table 1). The Banking Business Index and Shanghai A index each have negative correlations with Current Price Satisfaction $(-0.495$ and -0.588 , resp.) and positive correlations with Future Price Expectation (0.827 and 0.577, resp.). Insofar as banking business and share values tend to rise together, this could well reflect higher demands for 


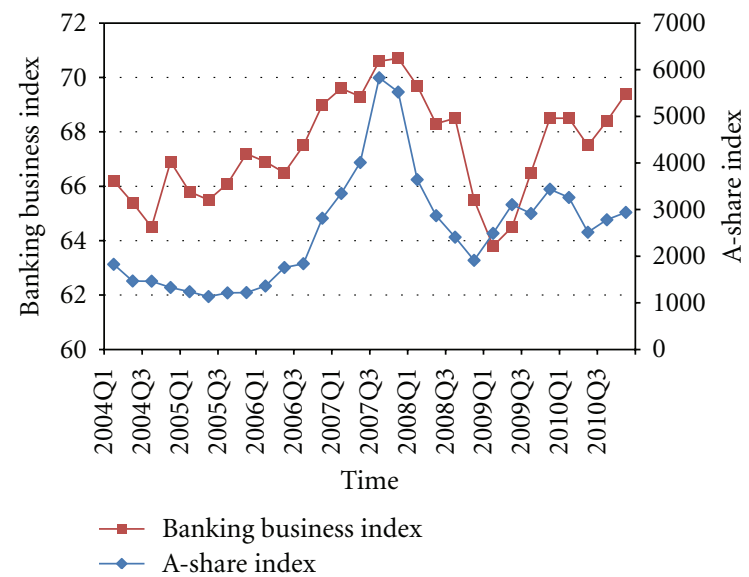

(a)

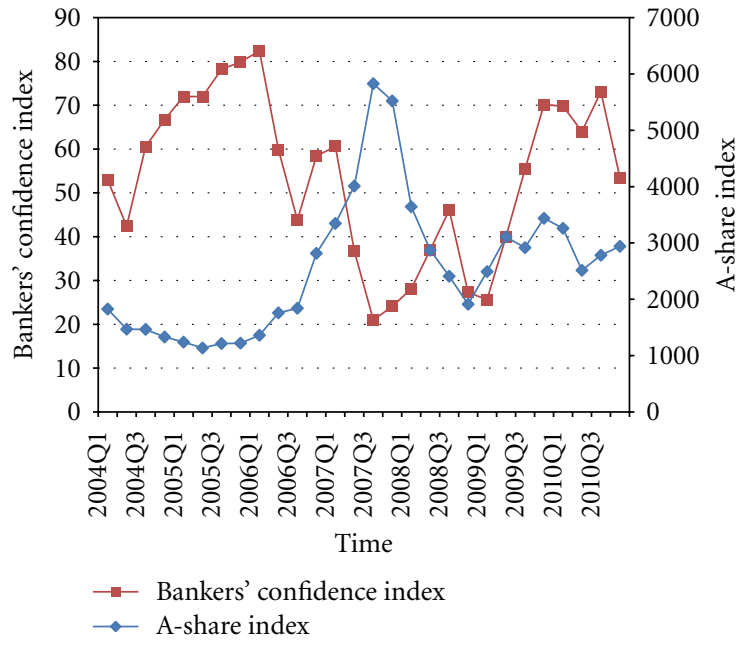

(b)

FIgURe 1: The two banking measures and the Shanghai A-share index, 2004-2010.

TABle 1: Simple Correlation Coefficients Between the Shanghai Market, the Banking Measures, and Inflation Expectations.

\begin{tabular}{|c|c|c|c|c|c|}
\hline & $\begin{array}{c}\text { Banking Business } \\
\text { Index }\end{array}$ & $\begin{array}{c}\text { Bankers' } \\
\text { Confidence } \\
\end{array}$ & $\begin{array}{l}\text { Current Price } \\
\text { Satisfaction }\end{array}$ & $\begin{array}{l}\text { Future Price } \\
\text { Expectation }\end{array}$ & $\begin{array}{c}\text { Shanghai A-Share } \\
\text { Index }\end{array}$ \\
\hline Banking Business Index & 1 & & & & \\
\hline Bankers' Confidence & -0.185 & 1 & & & \\
\hline Current Price Satisfaction & -0.495 & 0.233 & 1 & & \\
\hline Future Price Expectation & 0.827 & -0.087 & -0.505 & 1 & \\
\hline Shanghai A-Share Index & 0.724 & -0.597 & -0.588 & 0.577 & 1 \\
\hline
\end{tabular}

Note: All variables are in levels.

bank loans when asset prices are on the rise and concomitant overheating concerns are present in the economy. Meanwhile, Bankers' Confidence is negatively correlated with the Shanghai A index $(-0.597)$ and has a smaller positive correlation with Current Price Satisfaction (0.233) and negative correlation with Future Price Expectation (-0.087).

The tendency for Bankers' Confidence to move inversely with the stock market, in contrast to the Banking Business Index, can be seen in Figures 1 and 2. It seems that bankers are less prone to believe in normal, or steady, conditions at times when the stock market is rising. Meanwhile, Figure 3 offers further support for positive co-movement between the Banking Business Index and Future Price Expectation. In line with the relatively small correlation coefficients seen earlier, there is little clear-cut comovement between Bankers' Confidence and the price measures, however. Finally, Figure 4 offers visual confirmation of a negative relationship between the stock market and Current Price Satisfaction and a positive relationship with Future Price Expectation. An overall tendency for the Banking Business Index, the stock market and Future Price Expectation to move together is consistently indicated by the correlations and plots. Meanwhile, Bankers' Confidence seems to move inversely to the stock market but is not so clearly linked to the price series.
In order for formally test the significance of the relationships between the variables in question, we conduct a series of Granger-causality tests. The data are converted into log growth rates owing to unit roots in levels, with all series being stationary after conversion to growth rate form. ${ }^{11}$ Causality test results are based on Wald test statistics generated from vector autoregressions (VARs) for each pair of variables under a lag length of one for the quarterly data. ${ }^{12}$ The general form of the bivariate VARs is as follows:

$$
\begin{aligned}
& \Delta \ln (\text { Share })_{t} \\
& =\alpha_{1}+\beta \Delta \ln (\text { Share })_{t-1}+\delta \Delta \ln (\text { Banking })_{t-1}+\varepsilon_{1 t}, \\
& \Delta \ln (\text { Banking })_{t} \\
& =\alpha_{2}+\gamma \Delta \ln (\text { Banking })_{t-1}+\varphi \Delta \ln (\text { Share })_{t-1}+\varepsilon_{2 t} .
\end{aligned}
$$

Summary statistics on each data series are presented in Table 2 and the Granger-causality test results follow in Table 3. These results suggest that there is unidirectional causality running from the Shanghai A index to the Banking Business Index (at the 98\% confidence level) and from Bankers' Confidence to the Shanghai A index (at the $98 \%$ confidence level). Our finding that rising stock values give rise to increased banking activity, but not the reverse, 


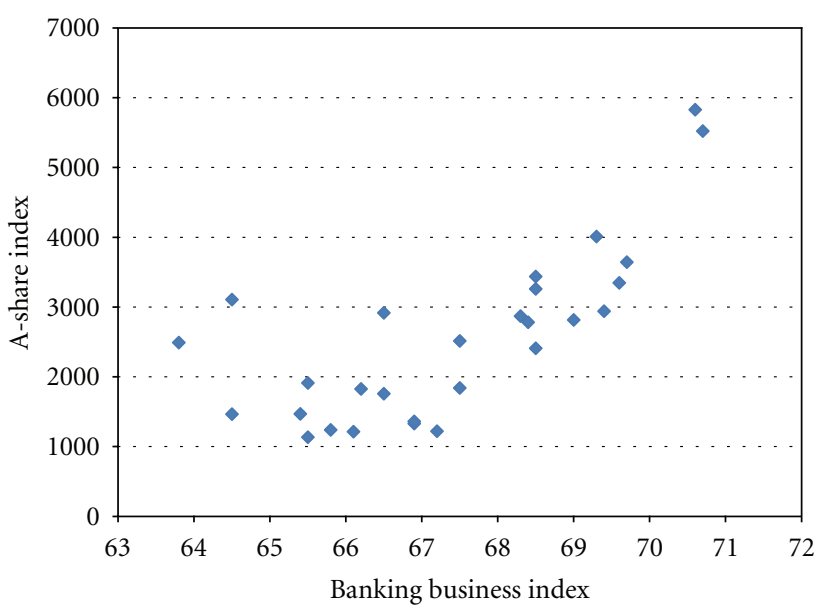

(a)

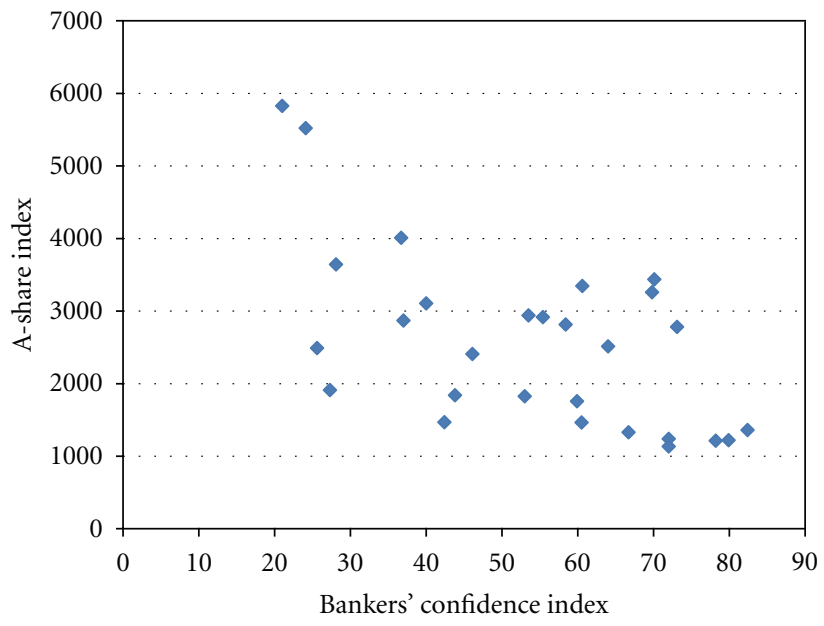

(b)

Figure 2: The Shanghai A-share index plotted against the two banking measures.

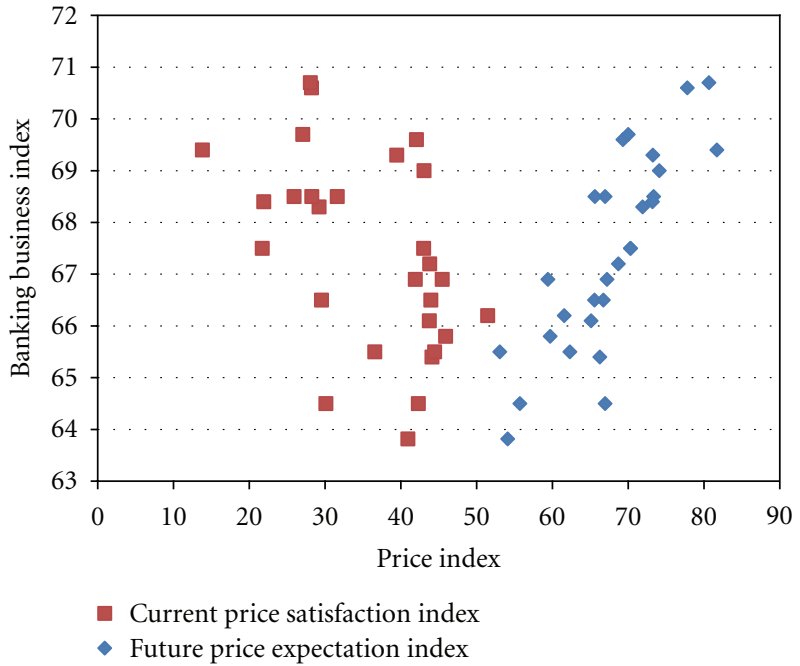

(a)

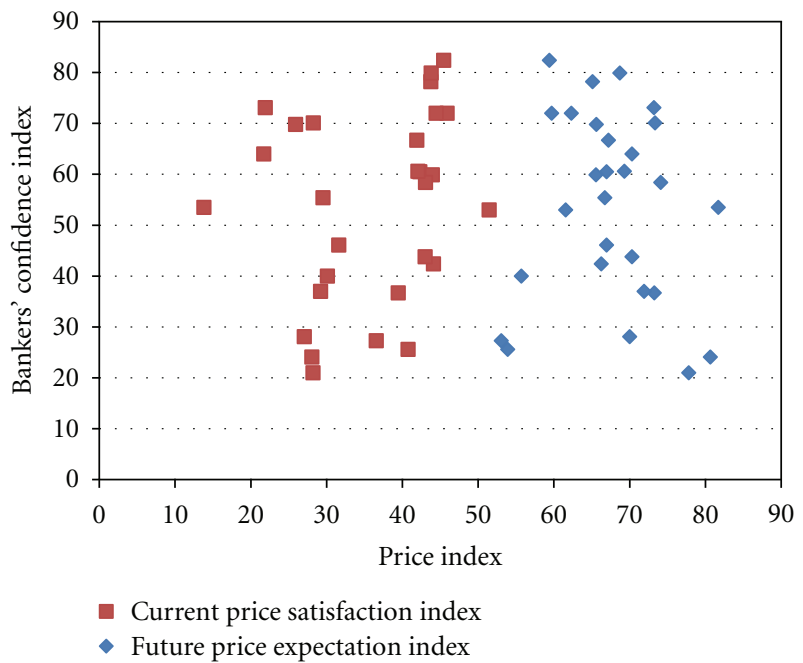

(b)

FIgURE 3: The two banking measures against current price satisfaction and future price expectation.

would support the premise that higher bank lending is itself driven by more buoyant market conditions-as opposed to being the actual cause of a surging market. Meanwhile, the suggested (negative) causal effect of Bankers' Confidence on the Shanghai A market implies that more widespread belief in normal or stable conditions is negative for the marketwhich would indeed generally be expected to benefit from more exuberant expectations.

Although there are no significant causal relationships between Current Price Satisfaction and the Banking Business Index, Future Price Expectation has a positive causal effect on the Banking Business Index that is significant at the $99 \%$ confidence level. The direction of this effect is consistent with the signs of the simple correlation coefficients laid out in Table 1. Higher Shanghai A index levels were themselves seen to be strongly positively correlated with Future Price Expectation (and also negatively correlated with Current Price Satisfaction) in Table 1. The relationships with the Banking Business Index appear to be strictly a one-way street, however, with banking business seemingly receiving a boost when share prices and inflation expectations are on the rise but having no detectable causal role in fueling such developments. Although it is not obvious that banking business would be boosted by inflation per se, higher demands for bank loans could be explained by the surging asset prices that accompany these overheating concerns as borrowers seek to take advantage of the more buoyant market conditions. Meanwhile, significant (negative) one-way causality running from the Shanghai A index to Current Price Satisfaction suggests that stock market booms may add to inflation 
TABLE 2: Summary statistics for the Shanghai index and survey data.

(a) All variables in levels

\begin{tabular}{|c|c|c|c|c|c|}
\hline Variables & Number of observations & Mean & Standard deviation & Minimum & Maximum \\
\hline Banking Business Index & 28 & 67.39 & 1.88 & 63.80 & 70.70 \\
\hline Bankers' Confidence & 28 & 53.63 & 18.50 & 21.00 & 82.40 \\
\hline Current Price Satisfaction & 28 & 35.97 & 9.42 & 13.80 & 51.45 \\
\hline Future Price Expectation & 28 & 67.52 & 7.22 & 53.05 & 81.70 \\
\hline Shanghai A-Share Index & 28 & 2559.36 & 1220.96 & 1135.12 & 5827.66 \\
\hline
\end{tabular}

(b) All variables converted to log growth rates

\begin{tabular}{|c|c|c|c|c|c|}
\hline Variable & Number of observations & Mean & Standard deviation & Minimum & Maximum \\
\hline Banking Business Index & 27 & 0.002 & 0.019 & -0.045 & 0.037 \\
\hline Bankers' Confidence & 27 & 0.0003 & 0.276 & -0.558 & 0.446 \\
\hline Current Price Satisfaction & 27 & -0.049 & 0.136 & -0.462 & 0.146 \\
\hline Future Price Expectation & 27 & 0.010 & 0.094 & -0.233 & 0.181 \\
\hline Shanghai A-Share Index & 27 & 0.018 & 0.204 & -0.416 & 0.425 \\
\hline
\end{tabular}

TABle 3: Causal relationships between the banking measures, inflation expectations, and the Shanghai A-index.

\begin{tabular}{|c|c|c|c|c|}
\hline Causal Relationship & Coefficient Sum & Chi-Squared Statistic & Number of Lags & Confidence Level \\
\hline Banking Business $\rightarrow$ Shanghai A & -0.023 & 0.937 & 1 & $66 \%$ \\
\hline Shanghai A $\rightarrow$ Banking Business & 0.041 & 5.387 & 1 & $98 \%$ \\
\hline Bankers' Confidence $\rightarrow$ Shanghai A & -0.311 & 6.516 & 1 & $98 \%$ \\
\hline Shanghai A $\rightarrow$ Bankers' Confidence & -0.230 & 0.814 & 1 & $63 \%$ \\
\hline Current Price Satisfaction $\rightarrow$ Banking Business & -0.050 & 2.214 & 1 & $86 \%$ \\
\hline Banking Business $\rightarrow$ Current Price Satisfaction & -0.239 & 0.026 & 1 & $13 \%$ \\
\hline Future Price Expectation $\rightarrow$ Banking Business & 0.149 & 16.815 & 1 & $99 \%$ \\
\hline Banking Business $\rightarrow$ Future Price Expectation & -1.104 & 0.951 & 1 & $67 \%$ \\
\hline Current Price Satisfaction $\rightarrow$ Banker's Confidence & -0.644 & 1.880 & 1 & $83 \%$ \\
\hline Banker's Confidence $\rightarrow$ Current Price Satisfaction & 0.060 & 0.375 & 1 & $45 \%$ \\
\hline Future Price Expectation $\rightarrow$ Banker's Confidence & 0.740 & 1.761 & 1 & $81 \%$ \\
\hline Banker's Confidence $\rightarrow$ Future Price Expectation & -0.062 & 0.846 & 1 & $64 \%$ \\
\hline Current Price Satisfaction $\rightarrow$ Shanghai A & 0.424 & 1.593 & 1 & $79 \%$ \\
\hline Shanghai A $\rightarrow$ Current Price Satisfaction & -0.299 & 6.127 & 1 & $98 \%$ \\
\hline Future Price Expectation $\rightarrow$ Shanghai A & 0.000 & 0.000 & 1 & $0 \%$ \\
\hline Shanghai A $\rightarrow$ Future Price Expectation & 0.117 & 1.588 & 1 & $79 \%$ \\
\hline
\end{tabular}

Note: The above statistics reflect Wald tests for Granger-causality based upon VARs estimated with one lag on each variable (all of which are in log growth rate form); relationships significant at the $90 \%$ confidence level or higher are depicted in bold print.

concerns but are not driven by them. Finally, there is no evidence of any significant causal relationships between the price series and Bankers' Confidence.

\section{Conclusions}

People's Bank survey data on banking activity, and inflation expectations support a causal relationship between inflation expectations, banking activity and the stock market during 2004-2010. The results imply that fears of inflation amidst surging bank lending and share prices are not just a figment of the 2009 experience but hold also over the sample period as a whole. While there is evidence of direct causal relationships between banking activity, inflationary pressures, and the stock market, the banking indicator seems to be driven by stock market moves and concomitant inflation concerns, rather than being the actual cause of any overheating that takes place. This leaves open the question of whether heightened bank lending is more a symptom than a cause of inflationary pressures in the economy, with the stock market seemingly moving before the banks. Finally, there is some support for a negative relationship between banker confidence and stock market strength. In general, stock market strength in China seems to be accompanied by rising inflationary concerns, increased bank lending activity, and reduced banker confidence that stable conditions will be maintained. This would seem to offer at least some justification for the People's Bank continuing to pay attention 


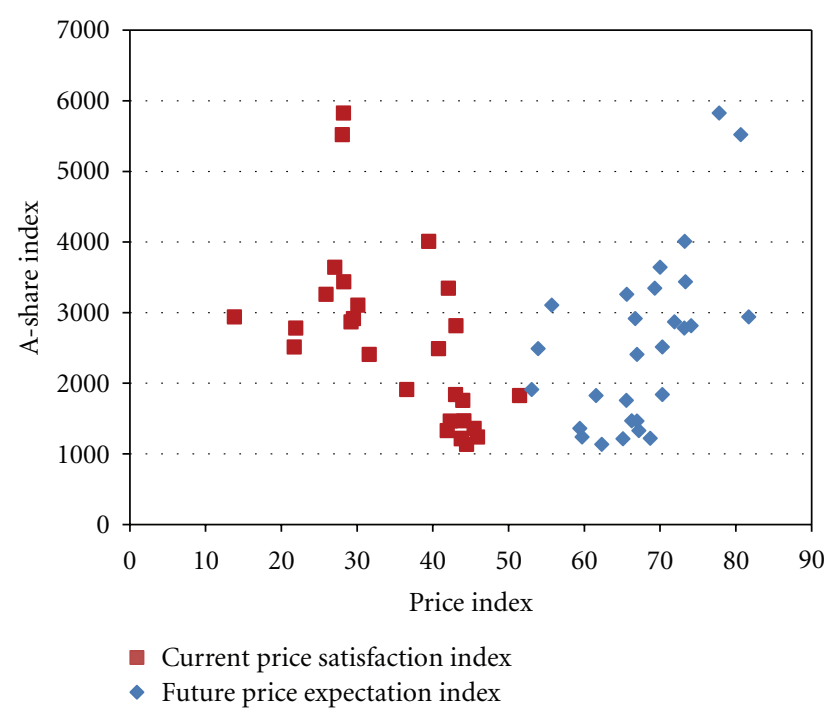

FIgURE 4: The Shanghai A-share index plotted against current price satisfaction and future price expectation.

to the stock market in determining its monetary policy stance and suggests that the Shanghai index might actually serve as a useful indicator variable in China. ${ }^{13}$

\section{Acknowledgments}

The authors thank Tom Willett and Li Jie for helpful comments and are grateful to Sze Wai Yuen for valuable research assistance most kindly funded by the Lowe Institute of Political Economy at Claremont McKenna College. An earlier version of this paper was presented at the Western Economic Association annual meetings in San Diego, California, June 29-July 3, 2011.

\section{Endnotes}

1. See "Expert warns more than RMB 1 trillion in new loans made their way to the stock market" (2009), July 6 [http://www.stnn.cc/chinafin/200907/t20090706_ 1058324_2.html] (in Chinese).

2. One reporter found that 28 of 30 business owners surveyed were engaging in such practices in mid-2009, typically taking out the loans solely because of the opportunity to play the market with the proceeds [9].

3. While no precise definition of "normal" is provided in the People's Bank survey materials, it implies a belief in stable operating conditions. Regular commentary on the two series is provided, in Chinese, in the "survey and statistics" section of the People's Bank website (http://test.pbc.gov.cn/publish/diaochatongjisi/193/ index.html).

4. For analysis of recent trends in Chinese bank balance sheets, and the relative position of the SOCBs, see, e.g., Lu et al. [10], Yao et al. [11], Cheng [12], Jia [13], Matthews et al. [14], Jiang and Yao [15], Luo and Yao
[16], Matthews and Zhang [17], and Burdekin and Tao [18].

5. As part of the efforts to bring bank lending rates back down, the CBRC acted to close a loophole that had allowed China's banks to move loans off their balance sheet by repackaging them as "trust products" [19].

6. Although the property market may also be sensitive to bank lending rates [20], real estate policy such as land supply plays a key role and has almost certainly distorted the relationship between house prices and economic fundamentals in China [21].

7. The A-share market for local investors is far more liquid than the separate B-share market for foreign investors and is the bellwether stock index for mainland China. For more details on the evolution of China's financial markets, and the different share classes, see, for example, Wong [22], Chan et al. [23], and Burdekin ([5], chapter 8). Rising market sentiment helped trigger a drawdown of savings accounts as local investors were increasingly drawn to the stock market $[24,25]$.

8. $\mathrm{CCB}$ and ICBC retained their top positions through the end of the year 2010 with BOC and ABC following in sixth and eighth place, respectively.

9. The banking survey series were subsequently reconfigured at the beginning of 2011 .

10. The stock exchange data are drawn from the Global Financial database (http://www.globalfinancialdata $. \mathrm{com} /$ ) and all other data are available from the People's Bank of China website (http://www.pbc.gov.cn/).

11. As an alternative to the end-of-quarter values for the Shanghai A index we considered quarterly averages. This had very little impact on the findings and led to no change in our inferences, but had the drawback of remaining nonstationary even after being converted into $\log$ growth rate form.

12. Although limited by the length of the available quarterly dataset, this parsimonious specification at least allows us to maintain 22 degrees of freedom for the causality testing. Allowing for longer lag lengths up to a maximum of four produced only two instances where the AIC criterion selected a lag length greater than one. The only effect such longer lag lengths had on the inferences was a suggested additional causal effect running from Current Price Satisfaction to the Shanghai A index under a lag length of four. We put less stock in this result as experimentation showed it to emerge only under this specific lag order and also because of the highly limited degrees of freedom when four lags are included in the VAR.

13. Zhao and Gao [26] advocate an even more widespread adoption of this approach encompassing housing prices as well as share prices.

\section{References}

[1] M. Moore, "Chinese stimulus cash is inflating new stock market bubble, officials warn," The Daily Telegraph, June 2009, 
http://www.telegraph.co.uk/news/worldnews/asia/china/ 5695924/Chinese-stimulus-cash-is-inflating-new-stockmarket-bubble-officials-warn.html.

[2] China Daily, "China's new credit rules put brakes on banks' lending binge," February 2010, http://www.chinadaily.com .cn/bizchina/2010-02/22/content_9483963.htm, (in Chinese).

[3] M. S. Gochoco-Bautista, "Asset price booms, "fat tails," and monetary policy in East Asia," Asian Economic Papers, vol. 8, no. 1, pp. 69-98, 2009.

[4] T. Ito, "Monetary policy and financial stability: is inflation targeting passé?" ADB Economics Working Paper Series no. 206, Asian Development Bank, Manila, Philippines, 2010, http://www.adb.org/Documents/Working-Papers/2010/ Economics-WP206.pdf.

[5] R. C. K. Burdekin, China's Monetary Challenges: Past Experiences and Future Prospects, Cambridge University Press, New York, NY, USA, 2008.

[6] G. C. Chow, "Will China have serious inflation?" Working Paper 1220, Center for Economic Policy Studies, Princeton University, 2010, http://www.princeton.edu/ceps/ workingpapers/205chow.pdf.

[7] L. Sun, J. L. Ford, and D. G. Dickinson, "Bank loans and the effects of monetary policy in China: VAR/VECM approach," China Economic Review, vol. 21, no. 1, pp. 65-97, 2010.

[8] S. Yao, D. Luo, and S. Morgan, "Bank share prices and stock market integration in greater China," Journal of the Asia Pacific Economy, vol. 15, no. 4, pp. 388-395, 2010.

[9] China Securities, "28 of 30 large stock market players acknowledge funding from bank loans," July 2009, http://www .cs.com.cn/, (in Chinese).

[10] Y. Lu, H.-G. Fung, and X. Jiang, "Market structure and profitability of Chinese commercial banks," The Chinese Economy, vol. 40, pp. 100-113, 2007.

[11] S. Yao, Z. Han, and G. Feng, "Ownership reform, foreign competition and efficiency of Chinese commercial banks: a non-parametric approach," World Economy, vol. 31, no. 10, pp. 1310-1326, 2008.

[12] Y. Cheng, "Reforms of the Agricultural Bank of China: can policy and commercial objectives be reconciled?" The Chinese Economy, vol. 42, no. 5, pp. 79-97, 2009.

[13] C. Jia, "The effect of ownership on the prudential behavior of banks - the case of China," Journal of Banking and Finance, vol. 33, no. 1, pp. 77-87, 2009.

[14] K. Matthews, X. Zhang, and J. Guo, "Nonperforming loans and productivity in Chinese Banks, 1997-2006," The Chinese Economy, vol. 42, no. 2, pp. 30-47, 2009.

[15] C. Jiang and S. Yao, "Banking reform and efficiency in China: 1995-2008," Research Paper 2010/11, Leverhulme Centre for Research on Globalisation and Economic Policy, University of Nottingham, Nottingham, UK, 2010, http://www .nottingham.ac.uk/gep/documents/papers/2010/10-11.pdf.

[16] D. Luo and S. Yao, "World financial crisis and the rise of Chinese commercial banks: an efficiency analysis using DEA," Applied Financial Economics, vol. 20, no. 19, pp. 1515-1530, 2010.

[17] K. Matthews and N. X. Zhang, "Bank productivity in China 1997-2007: measurement and convergence," China Economic Review, vol. 21, no. 4, pp. 617-628, 2010.

[18] R. C. K. Burdekin and R. Tao, "An ABC guide to provincial lending patterns in China: progress and prospects," The Chinese Economy, vol. 44, no. 5, pp. 34-54, 2011.
[19] D. McMahon, "China closes a lending loophole," August 2010, http://online.wsj.com/article_email/SB10001424052748704 164904575422490215350662-lMyQjAxMTAwMDEwMTEx NDEyWj.html

[20] Q. Liang and H. Cao, "Property prices and bank lending in China," Journal of Asian Economics, vol. 18, no. 1, pp. 63-75, 2007.

[21] H. Yu, "China's house price: affected by economic fundamentals or real estate policy?" Frontiers of Economics in China, vol. 5, no. 1, pp. 25-51, 2010.

[22] S. M. L. Wong, "China's stock market: a marriage of capitalism and socialism," Cato Journal, vol. 26, no. 3, pp. 359-424, 2006.

[23] K. C. Chan, H.-G. Fung, and Q. 'Wilson' Liu, Eds., China's Capital Market: Challenges from WTO Membership, Edward Elgar, Northampton, Mass, USA, 2007.

[24] R. C. K. Burdekin and L. Redfern, "Stock market sentiment and the draining of China's savings deposits," Economics Letters, vol. 102, no. 1, pp. 27-29, 2009.

[25] R. C. K. Burdekin and L. Redfern, "Sentiment effects on Chinese share prices and savings deposits: the post-2003 experience," China Economic Review, vol. 20, no. 2, pp. 246261, 2009.

[26] J. Zhao and H. Gao, "Impact of asset price fluctuation on China's monetary policy: an empirical analysis based on quarterly data, 1994-2006," Frontiers of Economics in China, vol. 5, no. 1, pp. 69-95, 2010. 


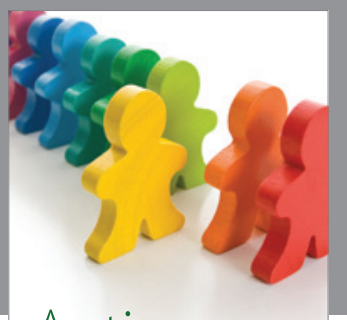

Autism

Research and Treatment
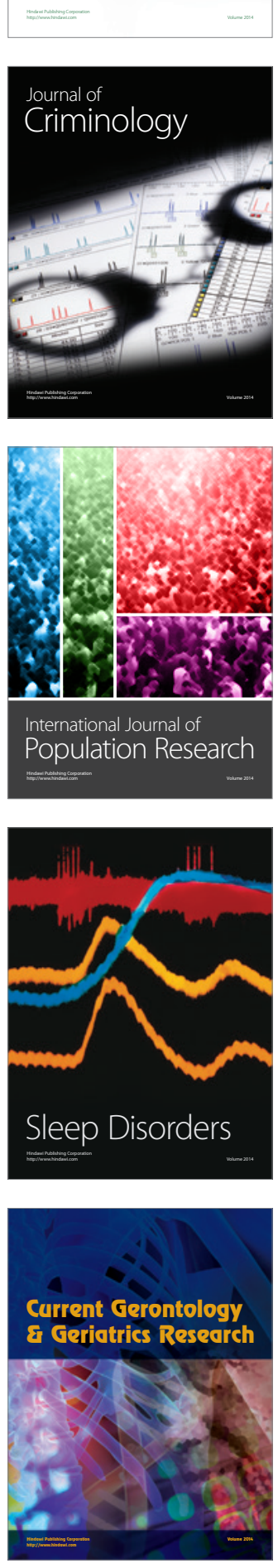
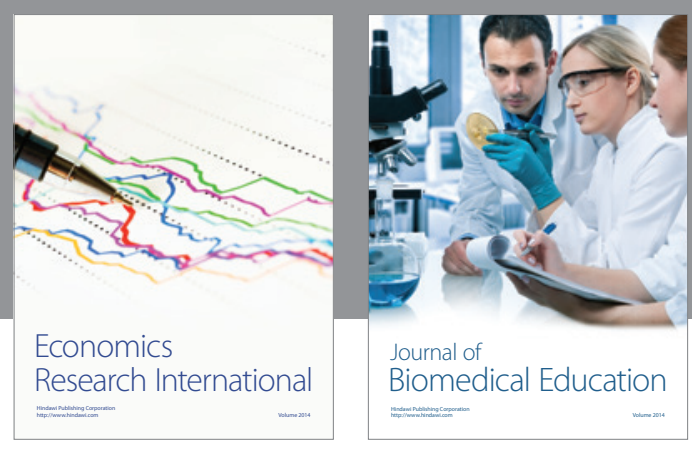

Journal of

Biomedical Education

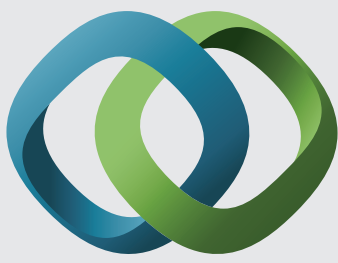

\section{Hindawi}

Submit your manuscripts at

http://www.hindawi.com
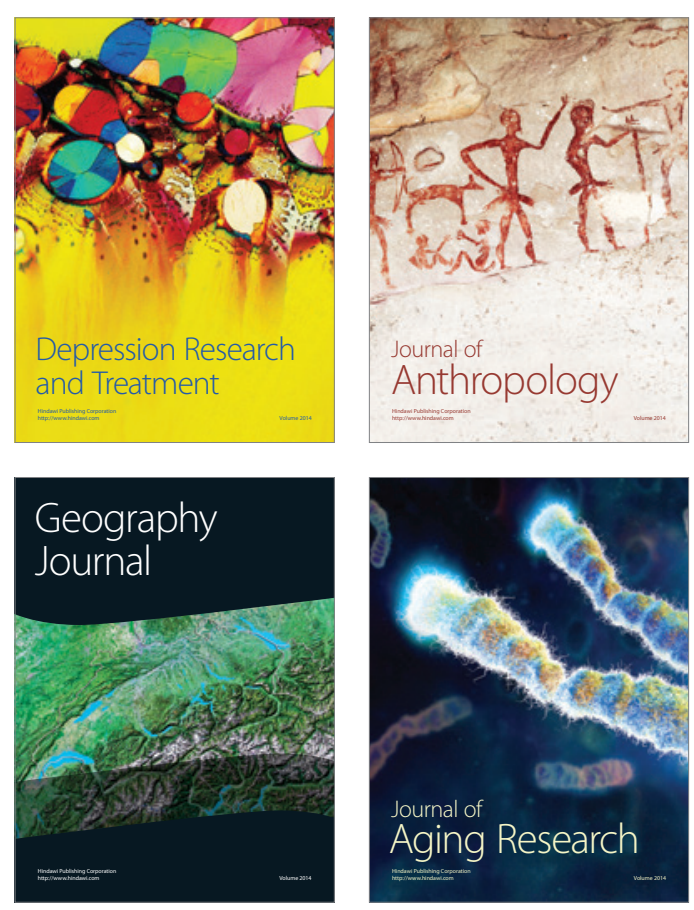

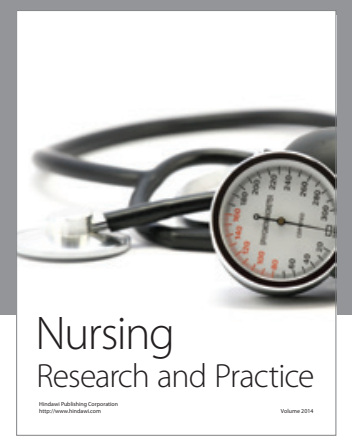

Nursing

Research and Practice

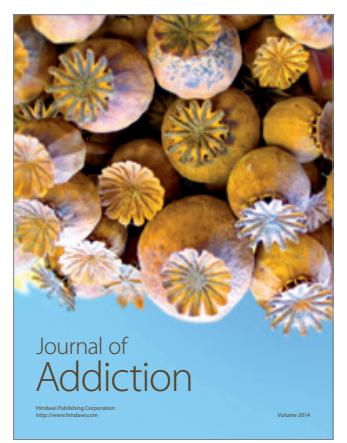

Child Development

Research

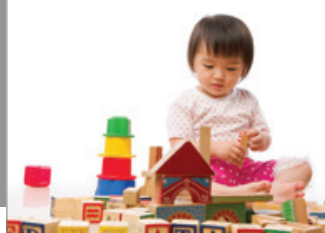

迥
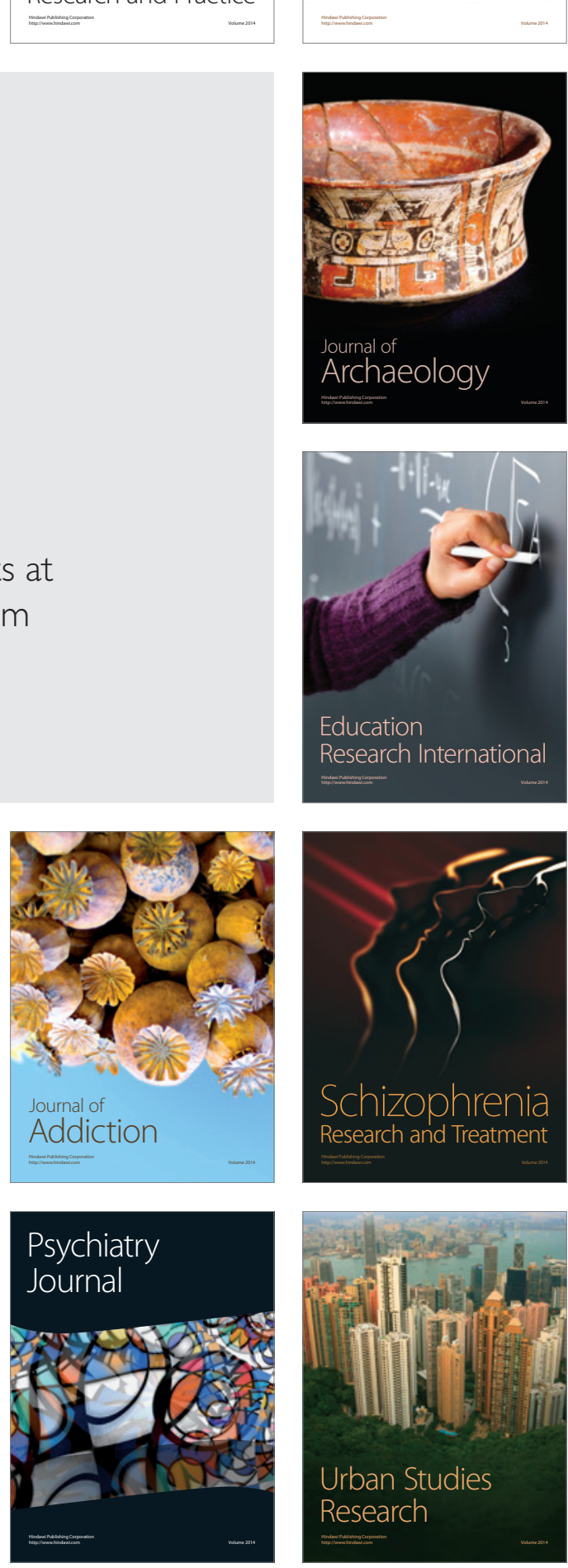